\title{
PNEUMOBILOK FEJLESZTÉSE ÉS ÉPÍTÉSE A MISKOLCI EGYETEM GÉP- ÉS TERMÉKTERVEZÉSI INTÉZETÉBEN
}

\author{
Bihari János \\ egyetemi docens, Miskolci Egyetem, Gép-és Terméktervezési Intézet \\ 3515 Miskolc, Miskolc-Egyetemváros, e-mail: machbj@uni-miskolc.hu \\ Tóbis Zsolt \\ mesteroktató, Miskolci Egyetem, Gép-és Terméktervezési Intézet \\ 3515 Miskolc, Miskolc-Egyetemváros, e-mail: machtzs@uni-miskolc.hu
}

\begin{abstract}
Absztrakt
Az elsö Pneumobil versenyt 2007. végén irták ki, és 2008-ban rendezték meg a Bosch-Rexroth egri gyárának szakemberei. A verseny célja, hogy egyetemi hallgatók olyan jármüveket tervezzenek és épitsenek meg, amelyek hajtásában pneumatikus alkatrészek alakitják át a süritett gáz energiáját mozgási energiává. A Miskolci Egyetem Gépészmérnöki és Informatikai Kara a kezdetek óta indit csapatokat ezeken a versenyeken. Ez a cikk röviden bemutatja magát a versenyt, valamint azt is, hogy a Gép-és Terméktervezési Intézetben a kar hallgatói milyen megoldásokat választottak, azokat hogyan kivitelezték, és milyen eredményeket értek el. Ez a cikk egy tervezett sorozat elsö része, a verseny bemutatására és a motorokra koncentrál.
\end{abstract}

Kulcsszavak: pneumobil, oktatás, pneumatika, automatizálás, gyakorlati képzés

\begin{abstract}
The first Pneumobile Competition was announced in the end of 2007 and held in 2008 by the professionals of the Bosch-Rexroth plant in Eger. The aim of the competition was to design and build such vehicles by university students where the pneumatic parts in the drive-chain convert the energy of the compressed gas into kinetic energy. The Faculty of Mechanical Engineering and Informatics of the University of Miskolc delegates teams to these competitions from the very beginning. This article briefly introduces the competition and the chosen solutions of the students of the Institute of Machine and Product Design, as well as the execution methods and their results.
\end{abstract}

Keywords: pneumobile, education, pneumatics, automation, practical training

\section{Bevezetés}

A pneumobil versenyeken a felsőoktatásban nappali tagozaton tanuló hallgatókból álló csapatok vehetnek részt. Korábban négy főben maximalizálták a szervezők a csapatok létszámát, most már 6 aktív és 6 segítő tagból álló csapatok is indulhatnak. A csapatok alapvető feladata az, hogy a szervezők által biztosított ipari pneumatikaelemek felhasználásával a versenykiírásnak megfelelő müködőképes jármüvet kell tervezniük és építeniük [1]. A jármüvek üzemanyaga kizárólag sürített nitrogén vagy levegö lehet. Igazság szerint ez csak az első versenyre volt igaz. Ma a feladat ennél jelentősen összetettebb, mert 13 év telt el az első rendezvény óta, és a jármüvek jelentősen fejlettebbek, mint az első két évben. Maga a feladat tulajdonképpen egy ipari automatizálási probléma, ahol pneumatikus munka- 
hengerek a végrehajtóelemek. Minden egyéb alkatrészt úgy kell kiválasztani és megtervezni, hogy a munkahengerek pontosan az elvárt időben hajtsák végre az elvárt feladatot.

A Miskolci Egyetemről minden eddig megrendezett versenyen indultak csapatok, ezeket az első két évben szerszámgépész és géptervező szakos gépészmérnök hallgatók alkották, akik a Gépelemek Tanszékén/Gép- és Terméktervezési Tanszéken, ill. a Szerszámgépek Tanszékén folytatták a tanulmányaikat, és a jármüveiket is ezeken a tanszékeken építették. A harmadik évben a pneumobilok építése teljesen a Gép- és Terméktervezési Tanszékre került, ezzel egy időben azonban megszünt a szakmai alapú klikkesedés, ebben az évben két csapat indult, amelyeknek tagjai vegyesen géptervezők, szerszámgépészek és villamosmérnökök voltak. Ettől kezdve a csapatok mindig több szakma képviselőiből szerveződtek. 2008 óta összesen 17 csapat indult a versenyen a Miskolci Egyetem színeiben, ezek nagy része legalább két évig müködött, legalább két járművet építve.

Ha erről a versenyről beszélünk, nem szabad megfeledkeznünk a szervezők elkötelezettségéről sem. Az első versenyt a Bosch-Rexroth Pneumatika Kft. szervezte meg, ezután a vállalat többször is tulajdonost váltott, de a szervezőgárda ugyanolyan elkötelezett maradt a verseny mellett. Időközben a vállalat a Rexroth-hoz került, majd Aventics Hungary Kft. néven élt tovább, ezután pedig az Emerson felvásárolta az Aventics csoportot. A szervezők és a csapatok elkötelezettségét látva minden tulajdonos támogatta a verseny megrendezését.

A verseny nagy mértékben hozzájárul a hallgatók szakmai fejlődéséhez. A terveikről független szakemberektől kapnak visszajelzéseket, a szerkezeteket megépíthetik és összemérhetik mások gépeivel. A fejlődésük jellemzően gyors, Kelemen László egy elemzésben [2] kimutatta, hogy egy év eltelte után a kezdetben teljesen tapasztalatlan versenyzők az élmezőnybe tartozó dokumentációkat képesek készíteni.

A Miskolci Egyetemröl eddig $\mathbf{5 9}$ hallgató vett részt ilyen versenyeken. Közülük 20 írt szakdolgozatot/diplomamunkát ebböl a témából, amelyek közül 17 jeles osztályzatot kapott, 1 közepes osztályzatot kapott, kettőt pedig idén fognak megvédeni.

A témában eddig 8 tudományos folyóiratban megjelent cikk készült, további három megjelenésre vár, ezen felül készült 6 TDK-dolgozat is.

A Miskolci Egyetem hallgatói 14 alkalommal álltak dobogón a különböző versenyeken, és számos különdíjat kaptak az évek során.

Ezek alapján kijelenthetjük, hogy ezek a versenyek nagyon hatékonyan támogatják a hallgatók szakmai fejlődését.

\section{A versenyszámok}

A pneumobil versenyeken négy alapvető versenyszámot kell teljesíteni, ezért minden jármüvet ennek megfelelően terveznek meg a csapataink. A csapatok többször is részt vesznek egyéb, főként alternatív hajtású jármüveknek kiírt versenyeken is, de ezekre nem tervezik át a jármüveket, a cél mindig a jó szereplés a pneumobil versenyen. A négy alapvető versenykategória a következő:

- Konstrukciós verseny

- Távolsági verseny

- Ügyességi verseny

- Gyorsulási verseny

A versenyszámok ismerete alapvetően befolyásolja a tervezési folyamatot és a későbbi optimalizálást is. Ezeken kívül minden versenyen számos különdíjat osztanak ki, de ezeket elöre nem ismertetik, így nem lehet a tervezéskor figyelembe venni őket. 
A konstrukció versenyszámban a zsüri a megtervezett jármüvet értékeli, első körben a dokumentáció alapján. A csapatok különböző szempontok szerint pontokat kapnak, amelyeket a konstrukció elfogadásakor meg is ismerhetnek. A fizikai versenyen a gépátvételkor bemutatják a zsürinek a jármüvüket, akik ekkor még egyszer ellenőrzik, hogy az mindenben megfelel-e az elöírásoknak, azaz sikerült-e a terveknek megfelelően megépíteni. Ezzel a hallgatók szakemberektől kapnak többszörös viszszajelzést, ami nagyban segíti a fejlődésüket. A konstrukció kategória lényeges eleme, hogy dobogós helyezést csak olyan jármü érhet el, ami a fizikai versenyszámok közül legalább egyben is dobogós helyezést tudott elérni.

A távolsági versenyszámban az a cél, hogy a jármü egy feltöltött, mindenkinél azonos mennyiségü levegőt tartalmazó palackkal a lehető legmesszebbre jusson el egy meghatározott pályán körözve. A verseny közben kötelező sofört váltani, valamint az átlagsebesség nem lehet egy meghatározott érték alatt. Ez a versenyszám korábban nem tartozott az izgalmasabbak közé, így sokan nem is készültek rá az egyetemünk csapatai közül sem. Ma a jármüvek fejlettsége elérte azt a szintet, hogy ebben a versenyszámban is izgalmas vetélkedések alakulhatnak ki. Ez a versenyszám többször változott a verseny történelme során, bevezették, majd növelték a kötelező minimális átlagsebességet, bevezették a soförváltásokat és növelték a számukat. Ennek ellenére erre a versenyszámra ugyanolyan elvek mentén kell tervezni, mint a kezdetekben.

Az ügyességi versenyszámban egy számos irányváltási kényszert tartalmazó pályán kell a lehető leggyorsabban végigmenni. Ez messze a legizgalmasabb megmérettetés, a legtöbb csapat elsősorban erre optimalizálja a járműveit, ez a Miskolci Egyetemen is sokáig így volt. Ez a versenyszám sokat változott a verseny története folyamán, és a népszerüsége miatt ezek a változások mindig új fejlesztési igényeket is hoztak magukkal. Ezt a jármüvek tervezésekor is figyelembe kell venni.

A gyorsulási verseny egy a klasszikus elveknek megfelelően megrendezett futam, egy kb. 200 méter hosszú pályán kell a lehető legrövidebb idő alatt végigmenni. Ez is egy látványos versenyszám, a versenyzők „karácsonyfa” lámpa jelére, párokban indulnak, de csak a mért idő számít az eredményben. Ez a versenyszám 2009 óta szerepel a programban, itt mindig is csak a puszta erő számított, azonban a versenytársak folyamatos fejlődése miatt itt is állandó a fejlesztési igény.

\section{A versenyhez kapcsolódó határidők és a csapatok feladatai}

Az 1. ábra összefoglalja a versenyhez kapcsolódó legfontosabb határidőket. A pneumobil versenyeket minden évben május elején rendezik meg. A versenykiírás az előző év szeptemberének végén jelenik meg, ekkortól lehet jelentkezni. A jelentkezés befogadása után csapatoknak december 31.-ig kell elkészíteniük a teljes tervdokumentációt, amelyet a felkészítő tanárnak ellenőrizni kell, és nyilatkoznia kell, hogy az megfelel a versenykiírásban elvártaknak. A csapatok ezután nyújthatják be elbírálásra a dokumentációt a zsürinek. Ismerve a hallgatóinkat a dátumból sejthető, hogy egy felkészítő tanár nem békés mulatozással tölti a Szilvesztert. A csapatoknak a vállalt rendelési rendszerében január első hetében kell leadniuk az igényelt elemek listáját, ehhez a vállalat katalógusait kell használniuk. Ez egy nagyon életközeli feladat, egyetlen kis elem sem maradhat ki, különben a pneumatikus rendszer nem fog tökéletesen müködni. Ezután a csapatok megkapják a zsüri értékelését a dokumentációról. Ez egyrészt fontos visszajelzés, hiszen független szakemberek értékelik a munkájukat, másrészt a továbblépés feltétele, mert a biztonság szempontjából releváns pontoknál nincs kibúvó, ha azok nem felelnek meg, a csapat nem indulhat a versenyen.

A korai versenyeken ettől a pillanattól kezdve már csak a májusi rendezvény következett, de nagyon gyakori volt, hogy egyes csapatok nem lettek készen, ezért a szervezők részhatáridőket vezettek be. Az első ilyen februárban van, ekkor be kell mutatni a jármü kész vázszerkezetét. A következő két 
héttel a verseny előtt, akkor videót kell készíteni arról, hogy a jármü működik. A részhatáridők bevezetése valóban eredményes volt, azóta nálunk is ritkább, hogy egy jármünek alapvető hibái maradnak, amelyeket a verseny közben kell javítani.

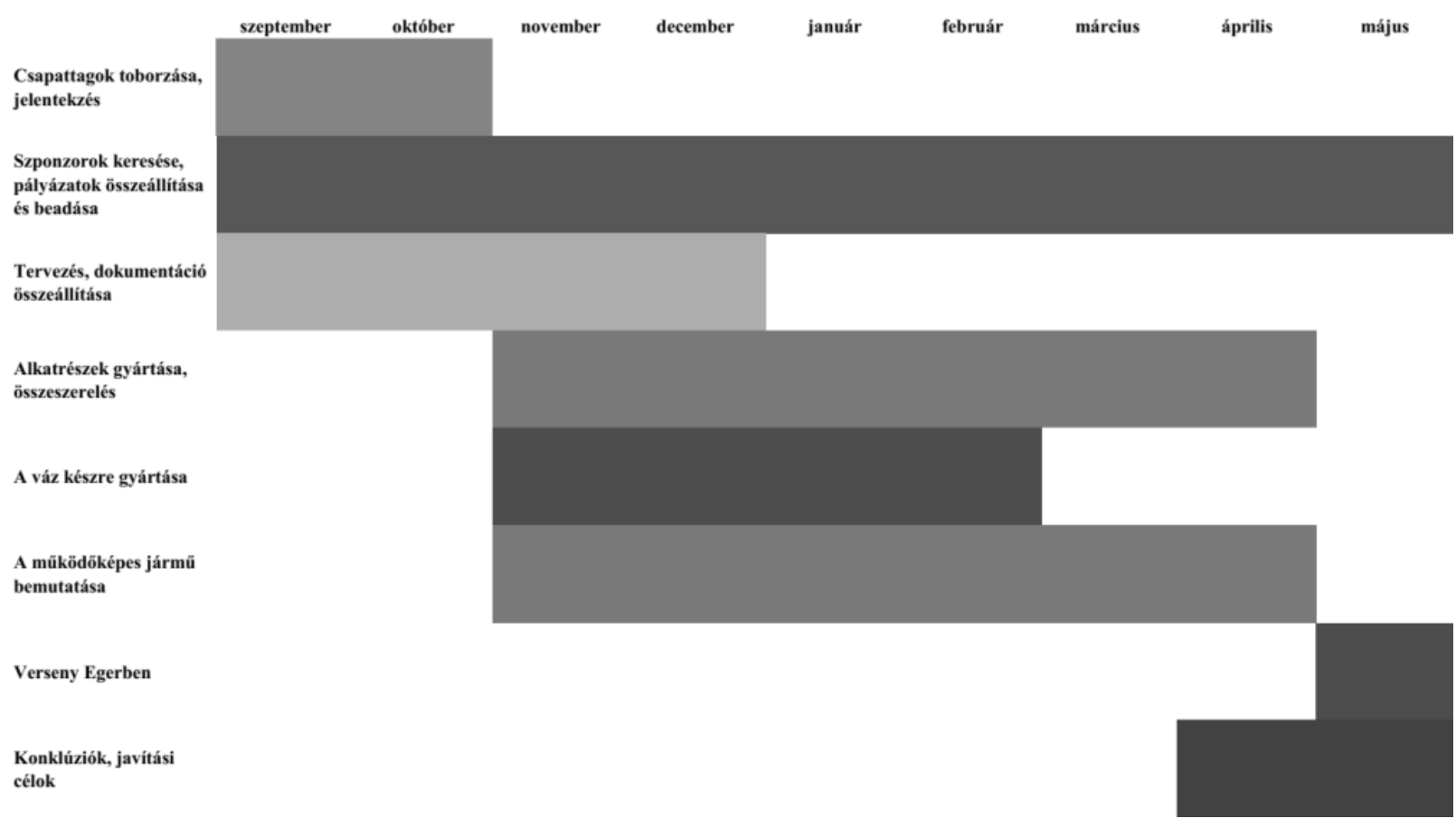

1. ábra. A pneumobil versenyek idörendje 2016 óta

A csapatok természetesen nem ülhetnek a babérjaikon a dokumentáció elkészítése után, egy pneumobil megépítéséhez anyagokra, szerszámokra, alkatrészekre és pénzre is szükség van, amit szponzoroktól kell megszerezniük. Egy ma versenyképes pneumobil esetén ez a pneumatikus elemek értékét leszámítva is azt jelenti, hogy legalább 800 ezer -1,5 millió forintot kell összegyüjteniük, de egy kezdő jármü megépítéséhez is szükség van kb. 300 ezer forintra. A szponzorok jelentős része szakmai alapon támogatja a csapatokat, elvárja, hogy az általa biztosított termékek vagy szolgáltatások felhasználásáról beszámolók készüljenek. Ezeket a verseny után még össze kell állítani. Az 1. ábrán ez a tétel nem szerepel, mert a határideje támogatónként változik.

\section{A pneumobilok motorjai}

A pneumobilok alapvető tervezési elveit a versenyszabályzat [1] határozza meg. Ennek megfelelöen: „A feladat egy olyan „pneumatikus jármü”- PNEUMOBILE - tervezése és elkészitése, amely a sürített levegö energiáját alkalmazva, pneumatikus vezérlö és végrehajtó elemek felhasználásával viszi át a nyomatékot a hajtott kerekekre."

A versenyszabályzat számos megkötést tartalmaz, de bőven hagy teret az egyedi müszaki megoldásoknak is. Az egyik legfontosabb megkötés, hogy a verseny kiírójának pneumatikus munkahengereiben kell a sürített levegő energiáját mozgási energiává alakítani. Ez azt is jelenti, hogy elöször mindig lineáris mozgásból kell kiindulnunk. Így a jármű mozgatásához kétféle átalakításra van szükség, ahogy ezt a 2. ábra mutatja. 


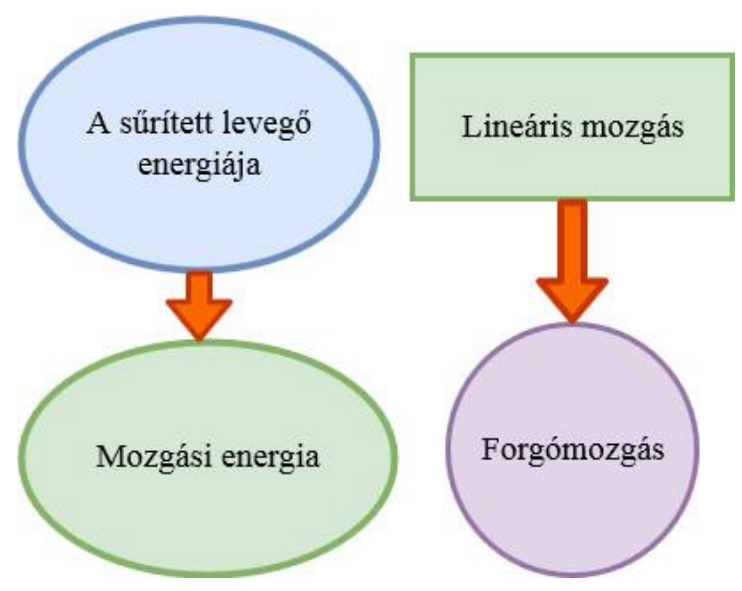

\section{2. ábra. Alapvetö átalakítások egy pneumobilban}

A sürített levegő energiájának mozgási energiává alakítása csak meghatározott eszközökkel és meghatározott módon történhet, a csapatok szabad kezet kapnak a lineáris mozgás forgómozgássá alakításában. A Miskolci Egyetem csapatai alapvetően négy megoldást alkalmaztak eddig a mozgások átalakításához:

- Forgattyús hajtómü

- Támolygó hajtómü (elsőként a verseny történetében)

- Lánchajtás

- Fogasléc-fogaskerék kapcsolat

\subsection{A forgattyús motorok}

A Gép- és Terméktervezési Intézetben kezdetben forgattyús hajtásokat építettek a hallgatók. A 3. ábrán az egyik éveken át használt megoldás alapelve látható. Ez 3 darab $63 \mathrm{~mm}$ dugattyúátmérőjü, 100 mm löketủ munkahengert tartalmaz. A pneumatikus munkahengereknél alapvető probléma, hogy az ezekkel müködő forgattyús hajtások lendkerék nélkül nem tudnak átfordulni a holtponton. A lendkerék alkalmazása, bár többször is felmerült az évek során, nem célszerü ezekben a járművekben. Ezért egy hengerrel nem oldható meg a teljes körülfordulás. A forgattyús mechanizmusban ezért öszszegezni kell a hengerek erejét, amit a mi hallgatóink elöször fogaskerekekkel oldottak meg. Ez egy könnyen megvalósítható (már amennyiben az embernek vannak megfelelö fogaskerekei), a gyártási pontatlanságokra kevésbé érzékeny, megbízhatóan müködő megoldás.

Ezeket a motorokat a Miskolci Egyetem csapatai 2008 és 2017 között használták. Ilyenek hajtották a KeSzKoSz, az Entrópia és a DAirp jármüveit. A KeSzKoSz csapat 2008-ban és 2009-ben versenyzett ilyen rendszerủ motorral. A motorban a hengerek háromszög alakban voltak elrendezve, a fogaskerekeknek külön forgattyúskarjai voltak, és a három meghajtó fogaskerék egy központi napkerekeket hajtott (4. ábra, balra fent). Ezt a megoldást azért választották, mert nagyon egyszerúen lehetett gyártani a mühelyben található eszközökkel. Az Entrópia ennek egy továbbfejlesztett változatát használta 2010 és 2014 között. Itt a hengereket egy síkba forgatták, így el lehetett hagyni a napkereket, a nagyobb fogaskerekek alkalmazása pedig lehetővé tette a külön karok elhagyását (4. ábra, jobbra fent). 

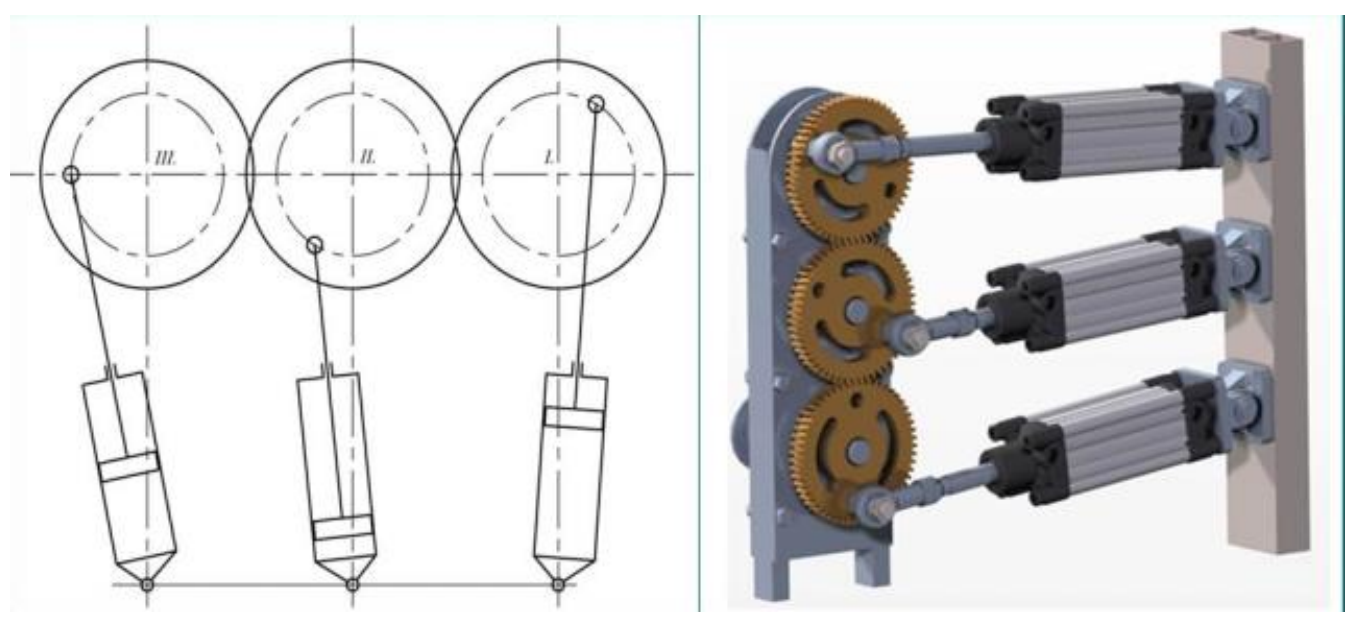

3. ábra. Háromhengeres forgattyús pneumotor és egy lehetséges megvalósitása

Ez azért volt lehetséges, mert eddigre a csapatok elkezdték kialakítani a szponzorok hálózatát, így tudtak egyedi fogaskerekeket gyártatni. Azonban ez csak állítva fért el a pneumobil hátsó részében, így rontotta a stabilitást. A DAirp megoldása (4. ábra. lent) ennek egy speciális verziója, az alapvető felépítésük azonos, de ez a pneumobil elejében, vízszintes helyzetben van elhelyezve. Így javítja a stabilitást, hátul pedig egy szöghajtómü biztosítja a kihajtó tengely megfelelő helyzetét. A motort és a szöghajtómüvet fogazott szíj köti össze. Ezt a kialakítást nem igazán a célszerüség motiválta, sokkal inkább az, hogy valami különlegeset, addig sosem látott müszaki megoldást készítsenek.

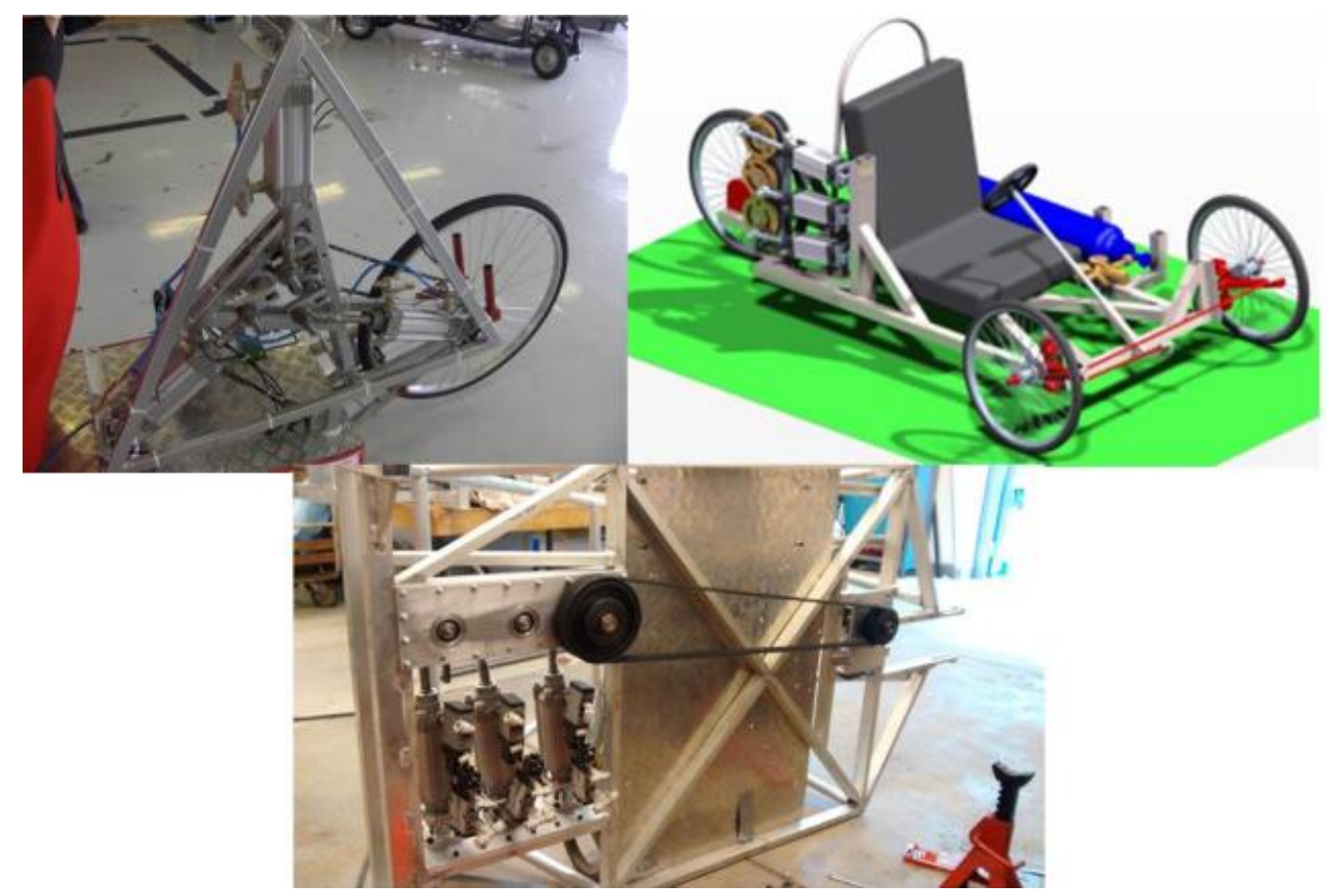

4. ábra. A háromhengeres forgattyús motor evolúciói 
Ezek a motorok nagyon megbízhatóak voltak, az ezekkel szerelt járművek sikeresen szerepeltek, minden csapat több versenyszámban is bejutott a 32-40 csapatból álló mezőnyök első felébe, több dobogós helyet is szereztek mind Egerben, mind különböző egyéb versenyeken. Azonban az ilyen motorok nagy hátránya, hogy a fogyasztásuk a rövid löketek miatt nem szabályozható jól, így a hosszú távú futamokon rosszak az esélyeik. Az olyan megbízhatósági versenyeken, mint a Széchenyi futamok voltak, a gyakori palackcsere miatt kerültek hátrányba. Ezen kívül a szabályok is úgy változtak, hogy az az ilyen motorok fejlesztése ellen hatott. Így egy kis intermezzo után a Miskolci Egyetem csapatai is elkezdték elhagyni ezeket a megoldásokat, bár a megbízhatóságuknak köszönhetően sokáig versenyeztek még, és folyamatos kihívást jelentett, hogy mennyit tudnak belölük kihozni.

Itt meg kell említeni, hogy a korai versenyeken az ügyességi futam három körböl állt, amelyek közül csak a legjobb kör ideje számított bele az értékelésbe. A fenti három jármü teljes gázon kb. 12001600 métert tudott megtenni egy palackkal, míg a pálya hossza kb. 420 méter volt. Ez sok más jármüre is igaz volt akkoriban, ezért hamar kialakult az a taktika, hogy az első körben óvatos gyorsítással takarékoskodva a célvonalon teljes sebességgel áthajtva a második körben próbáltak jó eredményt elérni, és ha a harmadikra nem maradt elég üzemanyag, az már nem számított. Ez pedig többeknek is megragadta a fantáziáját, ezek közé a többek közé tartozott a Miskolci Egyetem Puffogók nevü csapata is. Ök úgy döntöttek, hogy elég lesz 300 méter óvatos gyorsításra és 600 méter teljes gázra tervezni a jármüvet. A mozgásátalakításhoz forgattyús hajtóművet választottak, de a klasszikus, két forgattyúkaros kialakítással. A forgattyúkarokat ebben az esetben elég 90 fokkal elékelni, mivel a pneumatikus munkahengerek húzni is tudnak. A motorhoz $100 \mathrm{~mm}$ dugattyúátméröjü, $320 \mathrm{~mm}$ löketü hengereket választottak. A motor kialakítását az 5. ábra mutatja. A 6. ábra mutatja a motor nyomatéki görbéit, amelyekből látható, hogy ezeket a nyomatékokat már nem egyszerü feladat úgy kezelni, hogy a szerkezet ne legyen túl nehéz. Ezt a motort a töltés addig szokásos vezérlésével nem lehetett takarékosan üzemeltetni, óvatos hajtásnál is túl sokat fogyasztott. A nagy átmérőt lökethosszt kihasználva megoldható volt, hogy a hengert nem töltik a löket végéig, hanem csak bizonyos ideig, majd a gáz kitágulva alacsony nyomáson is megfelelö erőt képes létrehozni a jármü mozgatásához. Ez az expandálásnak nevezett módszer ma már általános, de a miskolci csapatok közül ők használták először. A 6 . ábrán látható, hogy a csúcsnyomaték ilyenkor $400 \mathrm{Nm}$-rel kevesebb, ami a forgattyú élettartamát is növelte.

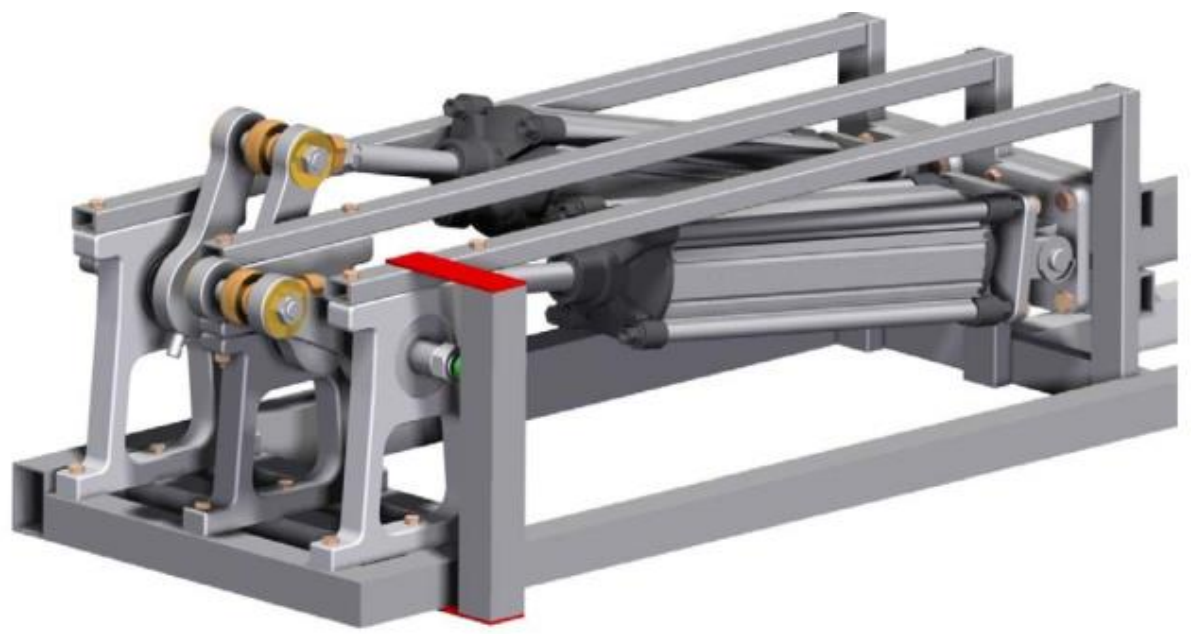

5. ábra. A Puffogók motorja 

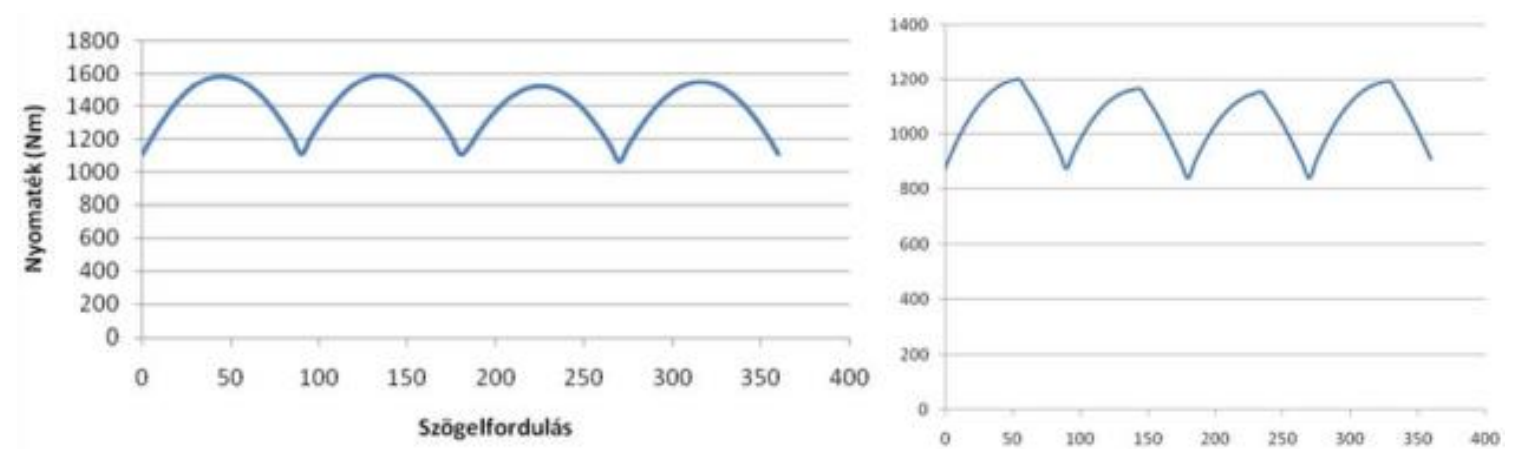

6. ábra. A Puffogók motorjának nyomatéki görbéi. bal oldalon teljes töltés, jobb oldalon expanzió (eredeti képernyömentések)

Az expandálási fok csökkentésével és vezérlésbe két üzemmód programozásával elérték, hogy ez a jármü kiválóan szerepelt a hosszútávú versenyeken is, nagy sebességet tudott elérni és ezt utána viszonylag takarékosan tudta tartani. A nagy sebességének köszönhetően ki tudta egyenlíteni a gyakori tankolásból származó hátrányát.

\subsection{Támolygótárcsás motor}

Ezt a motort 2010-ben építette a Szélhámosok csapat. Ez a csapat tapasztalt versenyzőkből állt, tudták, hogy ez a motor nem lesz igazán jó semmiben, de nagyon nehéz megvalósítani, és a müszaki kihívásokat keresték. A fő céljuk jó eredmény elérése volt a konstrukció versenyszámban. Ez sikerült is, második helyezést értek el, és a legötletesebb konstrukció különdiját is megszerezték.

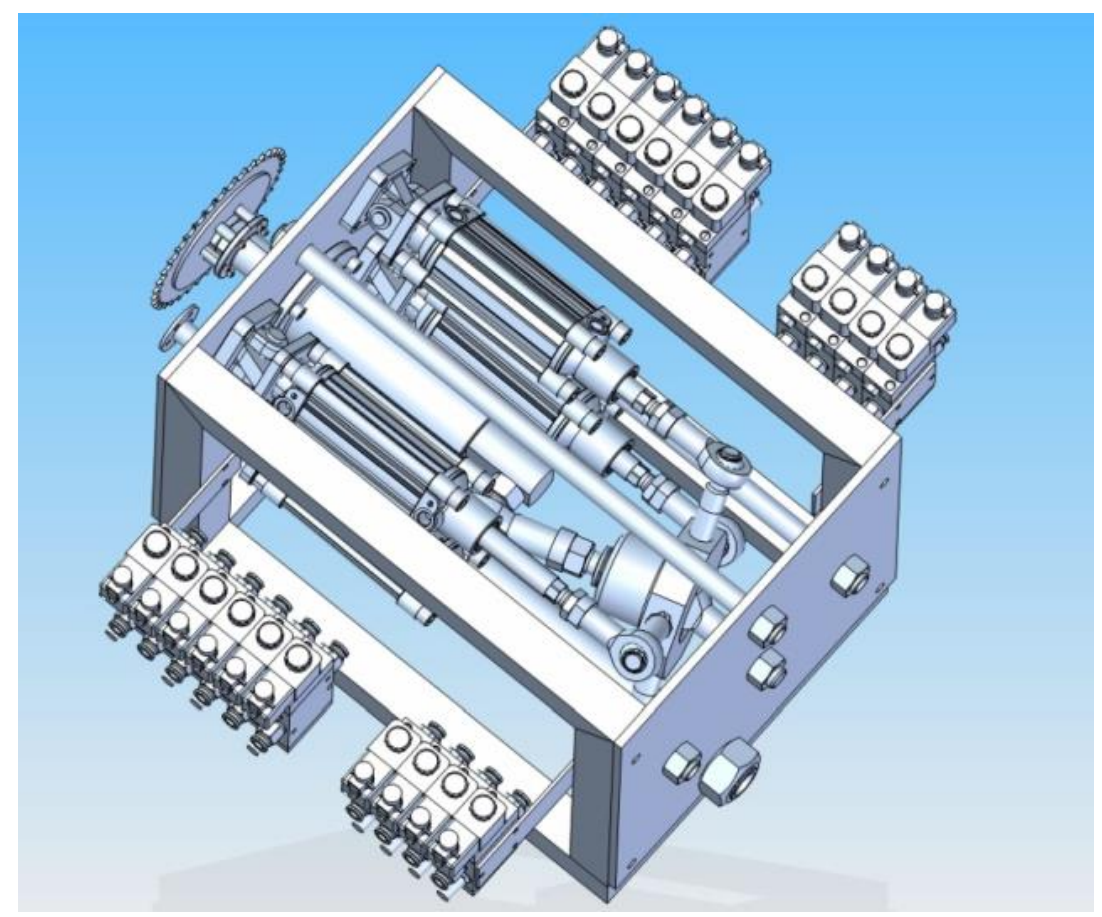

7. ábra. Támolygótárcsás motor 


\subsection{Lineáris motorok}

Ezek a motorok készültek lánchajtással és fogasléc-fogaskerékhajtással is. A pneumobilos zsargonban minden olyan motort lineárisnak nevezünk, amelyben a mozgás átalakítása ilyen módszerekkel történik, függetlenül a térbeli elrendezésektől és a tényleges pályáktól. A lineáris motorok erőleadása is lineáris, jól vezérelhetők, egyszerủ az expanzió alkalmazása is. A korai ügyességi versenyek kiskapuját felismerve a szervezők átalakították a szabályrendszert, először két kör összideje számított, majd eljutottunk a mai rendszerhez, amelyben Q1,Q2 és Q3 futamok vannak, egyre hosszabb pályákkal, így a jármüveknek egyszerre kell takarékosnak és erősnek lenniük. Ez hozta magával azt is, hogy nem érdemes külön csak egy versenyszámra tervezni, így a másik két fizikai versenyszám is jelentősen izgalmasabb lett. A mezőny első fele ma már kizárólag csak lineáris motorokat használ.

Az első lineáris miskolci motor egy láncos szerkezet volt, amely egyben egy sebességváltót is tartalmazott. Ezt a MekkMestAir nevü csapat építette és fejlesztette három éven át, közben szép sikereket elérve, köztük három dobogós helyezést és számos különdíjat is. Ebben a rendszerben a lineáris mozgást egy lánckeréken futó lánc alakítja át forgómozgássá. A lánc egy elmozdítható kocsin van bekötve egy karon, amelyet a munkahenger mozgat. A kocsi mozgatásával változtatható, hogy a munkahenger egy löketéhez mekkora láncelmozdulás tartozzon, azaz hogy hány fordulatot tegyen meg a hajtott lánckerék. A láncot segéd-munkahenger tartja feszesen állítás után. A munkahenger mindkét irányú mozgását kihasználták, ehhez két láncot építettek be és a két irányt szabadonfutókkal függetlenítették egymástól. Az egyik irányban beépítettek egy láncfordítót is, ami azt biztosítja, hogy a munkahenger mindkét irányú mozgásánál azonos irányba forogjon a kihajtó tengely. A rendszer elvi vázlatát a 8. ábra mutatja be.

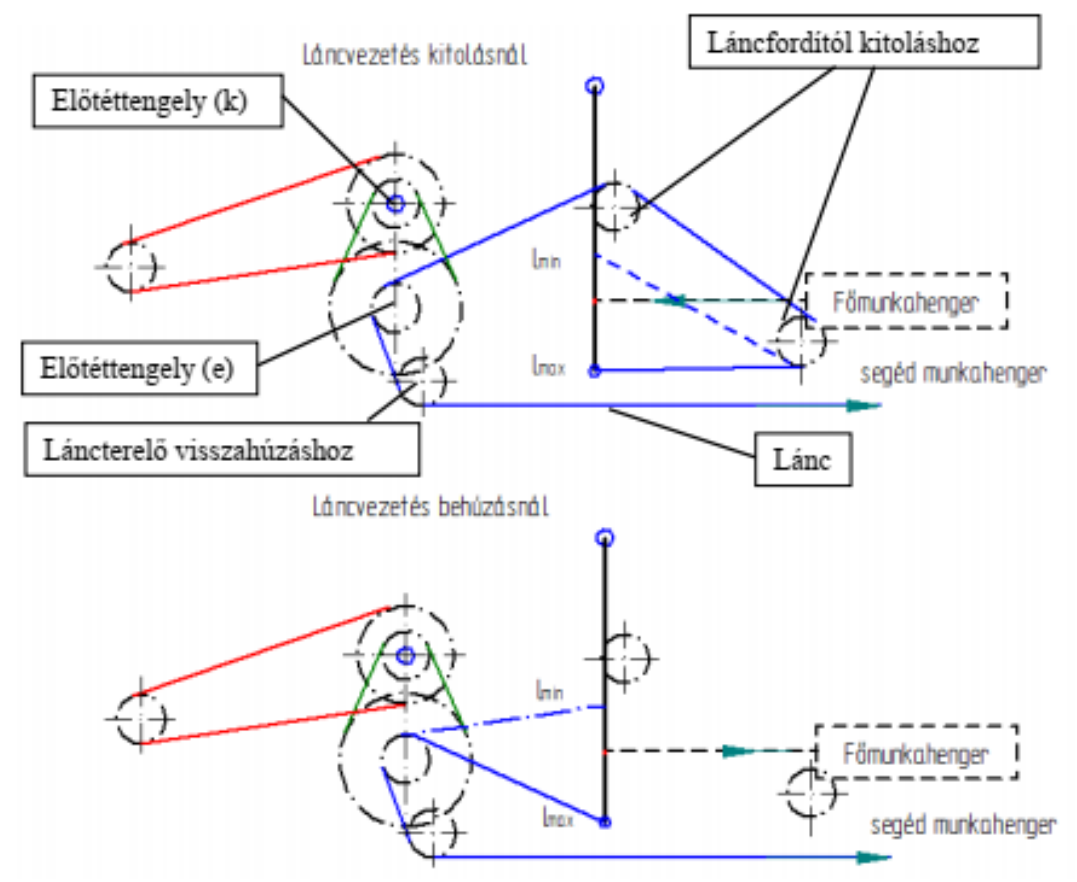

8. ábra. A MekkMestAir láncos hajtása 
Ez a rendszer többféle kivitelben is elkészült, 100/320 mm-es és 80/320 mm-es hengerrel is müködött. A segéd-munkahengerek mindig $300 \mathrm{~mm}$ hosszú, $50 \mathrm{~mm}$ dugattyú-átmérőjü hengerek voltak.

A lineáris motorok másik szokásos megoldása a fogasléces-fogaskerekes mozgásátalakítás. Ennél a munkahenger két irányának kihasználása nem jelent gondot, de maga a szerkezet jelentősen költségesebb elemekből áll, és pontosabb megmunkálásra és összeszerelésre van szükség ahhoz, hogy megfelelöen müködjön. Mind a láncos, mind a fogasléces megoldásban nagyon lényeges elemek a szabadonfutók. A záróelemek müködése alapvetően befolyásolja a motor müködését és minden, a motorban található és a motorhoz kapcsolódó alkatrész élettartamát. Ez azért van így, mert ezekben a rendszerekben semmiféle fojtást nem célszerü alkalmazni, ezért a munkahenger a szelep nyitásakor hirtelen nagy dinamikus terhelést ad a vele kapcsolatban lévő összes alkatrészre. Ha ilyenkor a szabadonfutó „kottyan”, az ilyen dinamikus terhelések károstó hatása is megnő. Ezért jellemzően minden csapat ipari szabadonfutókat használ, amelyeknek az ára és a mérete nagy mértékben függ a terhelhetőségüktöl. A csapatok költségvetéseit tekintve az ár sem elhanyagolható tényező, de a nagy méretü szabadonfutók beépítése különösen nehéz lehet. Ezért mindenki igyekszik úgy tervezni, hogy a szabadonfutókat a lehető legkisebb nyomaték terhelje, ez pedig mindkét rendszernél azt jelenti, hogy a fordulatszámot minél nagyobb értékig kell növelni a mozgásátalakító rendszer forgó tengelyén. Ezt fogaslécfogaskerék kapcsolattal jellemzően egyszerübb megoldani, így a szerkezet jelentősen kompaktabb lehet. Miskolcon az első ilyen rendszerü motort a BSTM nevü csapat építette, a felépítését a 9. ábra mutatja. Ez a motor két darab 100/500 mm-es munkahengert tartalmaz, de a lineáris kialakítása miatt a nyomatékleadása egyenletes. Így alacsony nyomásról is tud expandálni, ami a kb. 11 literes összkamratérfogat ellenére is takarékos üzemet tesz lehetővé, ugyanakkor nagy nyomásnál nagy teljesítménnyel is müködhet a motor. Az egyirányúsítás itt egy fogaskerékpárral van megoldva, ami a szerkezet belsejében kapott helyet, így a jármüben jelentősen kevesebb helyet igényel, mint egy láncfordító.

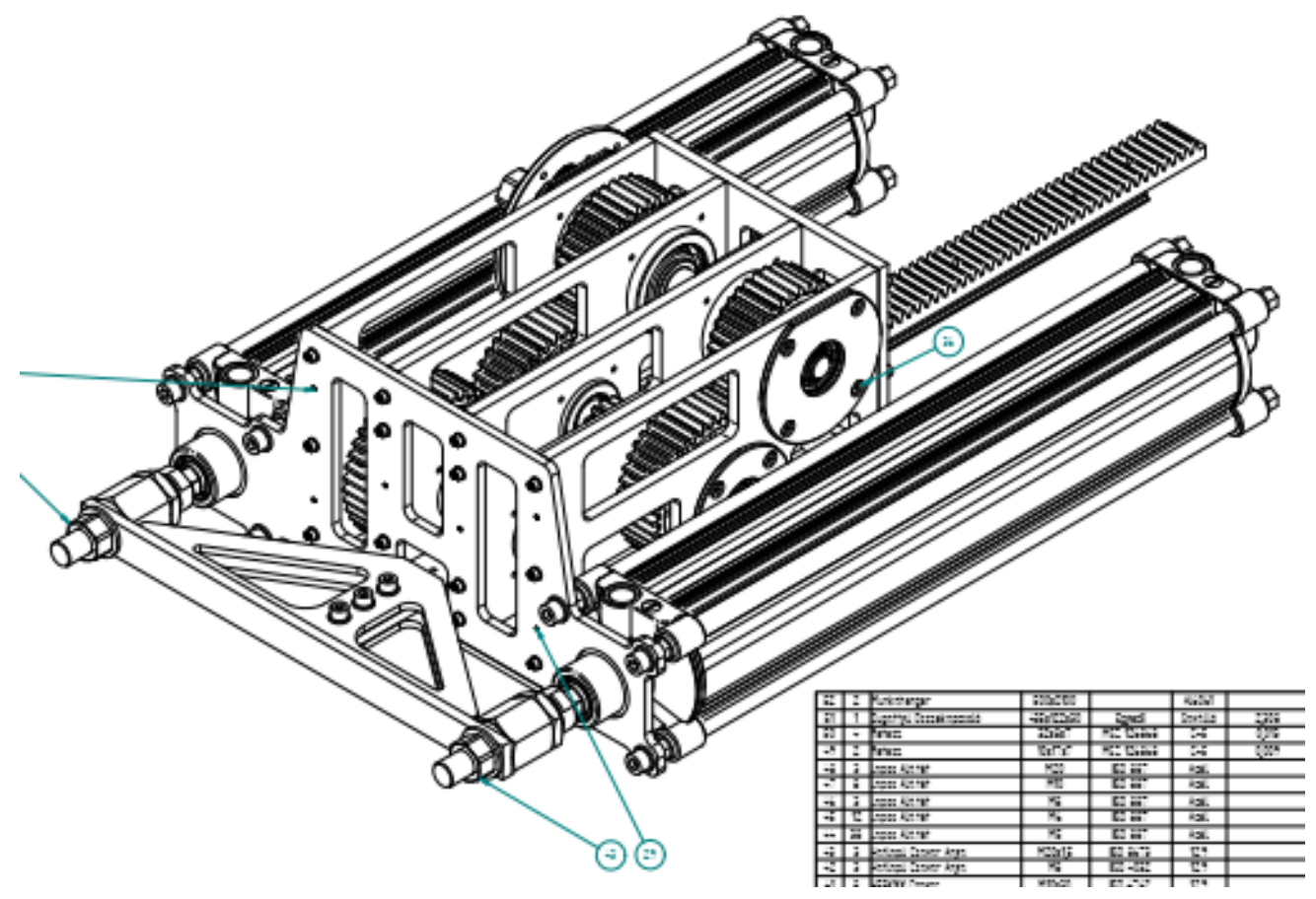

9. ábra. A BSTM fogasléces motorjának felépitése 
A jelenleg aktív csapatok alapvetően csak lineáris hajtásokat használnak. A versenyszabályzat egyik módosításával 2016-ban betiltották az új ráülős (a pneumobilos terminológia szerint quad kialakítás, bár a többségük háromkerekü volt) jármüvek építését. Ezzel újra előtérbe került a motorok helyigénye a vázon belül. Azóta két új iskola alakult ki a miskolci csapatoknál, a nagyon egyszerü láncos, és a bonyolultabb, de soros elrendezésü fogasléces motoroké.

2016-ban a Miskolci Egyetem csapatai a szokásosnál rosszabbul szerepeltek a versenyen, aminek elsősorban az volt az oka, hogy egyre nehezebb lett megfelelő támogatókat találni, az aktív jármüvek elhasználódtak, a javításuk eszközigényes volt. Ezért az egyik újként szerveződő, de tapasztalt és új tagokból álló csapat, az AkiMEAir, egy olyan motort tervezett, amit egyszerü elemekből és kereskedelmi forgalomban kapható olcsó alkatrészekböl egyszerü eszközökkel is le lehet gyártani (10. ábra). Ebben a motorban is két 100/500 mm-es munkahenger van, amik önmagukban jelentős értéket képviselnek, de ezeket a szervezők biztosítják a versenyhez. A motorban nem használják ki a hengerek mindkét irányát, hanem a dugattyúoldali kamrákat vákuumozzák, majd összekötik, és csak a rúdoldali kamrák müködnek, azaz a két henger felváltva húz, míg a lánc feszítését a vákuum biztosítja. Az egyirányúsítást fogaskerékpárral oldották meg, így a motornak csak két tengelye van. Ez a szerkezet nagyon megbízhatónak bizonyult, jelenleg a negyedik fejlesztett változata készül a 2020 -as versenyre.

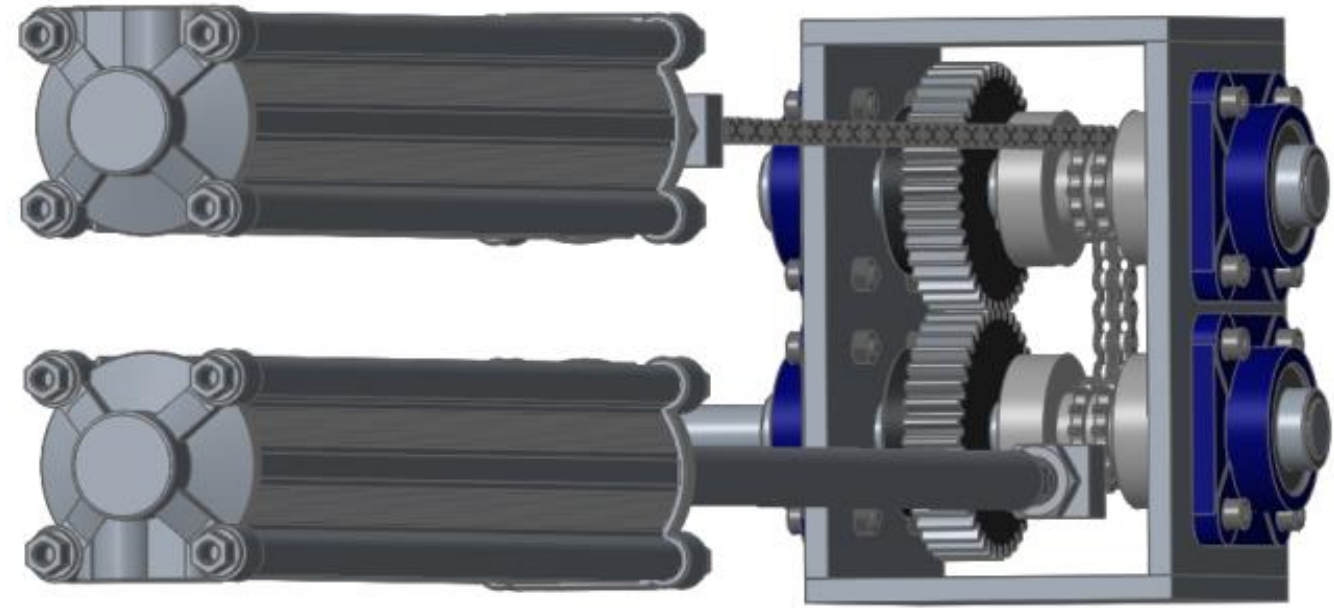

\section{0. ábra. Az AkiMEAir motorja}

Ez a motor viszonylag magas, ezért a jármüben jól kell elhelyezni. Mivel az ügyességi pálya legerősebb kanyarjaiban balra kell fordulni, fontos, hogy a jármü bal oldalára kerüljön. Az egyszerüségének köszönhetően a korábbi példányok mobil tesztlaborként is szolgálnak, az eddigieknél jobban tanulmányozhatók rajtuk a kamrákban kialakuló nyomásviszonyok, mert kevesebb mechanikai tényező befolyásolhatja az eredményeket, mint a bonyolultabb szerkezeteknél.

A másik mostanában alkalmazott motortípus a soros elrendezésű fogasléces motor. Az első ilyet az Airmeks csapat tervezte és építette. Az alapelve megegyezik a 9. ábrán látható motorral, de a munkahenger a fogasléccel egy vonalban helyezkedik el, így a munkahenger elfér a vezető mellett. Ez a motor a 11. ábrán látható. Ilyen motort csak egy munkahengerrel érdemes építeni, de időközben a vezérlések olyan szintre fejlödtek, hogy egy hengerrel is megfelelö teljesítményt lehet elérni. 


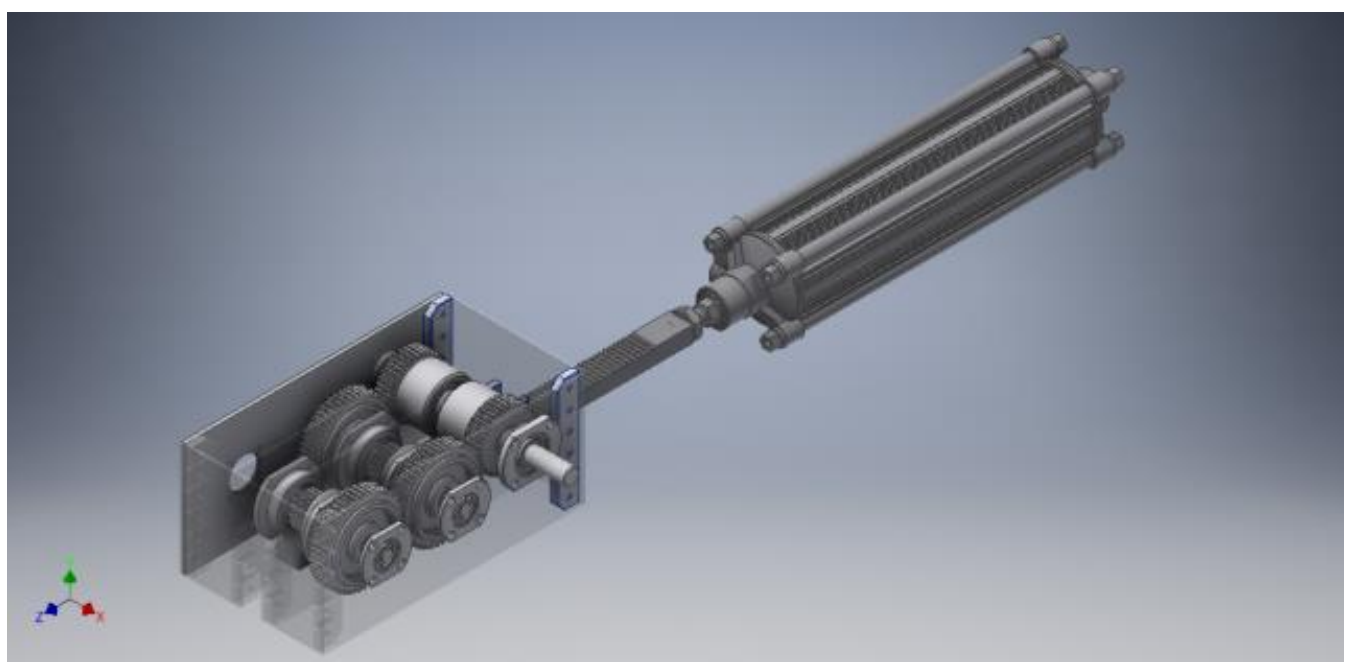

11. ábra. Az Airmeks motorja

\section{5. Összefoglalás}

Ahogy a bevezetőben is említettük, ezt a cikket egy sorozat első részének szánjuk. Egy pneumobil gyakran esetlen, tapasztalatlan kezek által készített testében meglepően sok modern technológia rejtőzhet és müködhet jól, pl. a XX. század elejének megoldásai keveredhetnek a XXI. század modern vezérléseivel. Többek között ez adja ennek a versenysorozatnak a speciális báját. Ezért úgy gondoljuk, hogy érdemes bemutatni, hogy fejlődött és változott a pneumobilok többi része, így a karosszéria és futómü, vagy akár a motorok vezérlése. Reméljük, ebben a cikkben sikerült bemutatnunk, hogy a Miskolci Egyetem hallgatói mennyire kreatívak tudnak lenni, ha hagyjuk őket szárnyalni.

A cikkben megjelenő ábrák közül a motorokat ábrázoló valamennyi ábra a hallgatók munkája.

\section{Köszönetnyilvánítás}

A szerzők köszönetet mondanak a versenyek megalkotónak és szervezőinek, a csapatok tagjainak, az ellenfeleknek, akik miatt folyamatosan fejleszteni kell a saját képességeinket is, valamint a Miskolci Egyetem Gépészmérnöki és Informatikai Karának és Hallgatói Önkormányzatának és az összes támogatónak a kapott támogatásokért.

\section{Irodalom}

[1] https://pneumobil.hu/pneumobil_2020/versenykiiras_es_szabalyzat/versenykiiras_dijazas_2020 (hozzáférés dátuma: 2020. január 3.)

[2] Kelemen, L.: Studying through the Pneumobile competition In: Pokorádi, L. (szerk.) Proceedings of the 1st Agria Conference on Innovative Pneumatic Vehicles - ACIPV 2017, Budapest, Magyarország, Eger, Magyarország, Óbudai Egyetem, (2017) pp. 23-26. 